KARANGAN: Jurnal Kependidikan, Pembelajaran, dan Pengembangan, Vol 3, No 2, Bulan September, Tahun 2021, Hal 116-121

\title{
THE IMPOLITENESS STRATEGIES OF EMINEM'S SONGS
}

\author{
Lilik Suryani ${ }^{1}$, Rajid Khurniawan ${ }^{2}$ \\ English education study progam, Billfath Univercity
}

\section{INFO ARTIKEL}

Diterima : 31-7-2021

Disetujui :3-9-2021

\begin{abstract}
Abstrak: Eminem adalah seorang penyanyi Amerika yang sangat terkenal.Dia adalah seorang penyanyi Rap terbesar di dunia. Dengan penjualan album lebih dari 47,4 juta dan lebih dari 107,5 juta album single terjual di Amerika dan 220 juta di seluruh dunia. Eminem disebut sebagai salah satu musisi dan penulis lagu terbaik di dunia permusikan. Eminem adalah sosok yang sangat kontroversial Tetapi lagu-lagu Eminem sangat kontroversial dan penuh kata-kata kotor. Di dunia ini, Eminem mungkin adalah satu-satunya musisi yang mampu menggunakan kata-kata kotor didalam lirik lagu-lagunya untuk menghipnotis pendengarnya. Penelitian ini bertujuan untuk menganalisa lagu Eminem denagn teori Impoliteness dari Culpeper(1996). Penelitian ini menggunakan diskriptif qualitatif. Penelitian ini bertujuan untuk menemukan strategi impoliteness apa saja yg ada dalam lagu-lagu Eminem dan teori impoliteness apa yang paling sering muncul di lagu Eminem. Peneliti mengambil 3 lagu sebagai data yaitu Marsahall Mathers, Kill you dan Kim. Hasil dari penelitian iniadalah sebagai berikut. Total ketidaksopanan yang digunakan Eminem dalam lagu - lagunya adalah 83 data. Data ketidaksopanan total ada 11 data $(13,25)$, ejekan (ketidaksantunan negatife) 6 data $(9,63 \%)$, penggunaan kata - kata tabu 56 data $(67,46 \%)$, sarkasme 1 data $91,20 \%)$, memanggil nama lain 1 data $(1,20 \%)$, menggunakan penanda identitas yang tidak tepat 1 data $91,20 \% 0$, mengecualikan yang lain dari aktivitas 1 data $(1,20 \%)$, menakut - nakuti 8 data $(9,6 \%)$. Dan strategi yang paling sering digunakan Eminem dalam lagunya adalah menggunakan kata - kata tabu 56 data $(67,46 \%)$.
\end{abstract}

Kata Kunci:

Pengembangan,

Modul IPA, Etnosains,

Jiwa Konservasi

\begin{abstract}
Eminem is a famous American singer. He is one of the greatest Rapper in the world. With over 47.4 million albums and 107.5 million singles sold in America and 220 million records globally. Eminem is declared one of the best and one of the most influential writers in the history of music industry. But Eminem music was very controversial. Eminem's songs are controversial and full of dirty lyric. And in this world, Eminem is perhaps the most successful musician who is able to use dirty lyric or impolite utterance to hypnosis his listener. This research investigated the impoliteness in the Eminem songs title Kill You, Marshall Mathers and Kim. This research used a qualitative descriptive method. The researcher used the theory of impoliteness from Culpeper (1996) to analyze Eminem's songs. This research investigated what kinds of impoliteness strategies used by Eminem in his songs and what is the most frequently impoliteness strategies used by Eminem in his songs. The researcher took three of Eminem songs to be analyzed title Kill you, Marsahall Mathers and Kim. The research results that have been found include the following. The total impoliteness used by Eminem in his songs is 83 data. The total data of impoliteness are bald on record 11 data(13,25\%),ridicule(negative impoliteness) 6 data $(9,63 \%)$,use taboo words 56 data( $67,46 \%)$,Sarcasm 1 data( $(1,20 \%)$, call the other names 1 data( $1,20 \%)$,use inappropriate identity markers 1 data $(1,20 \%)$,exclude the other from an activity 1 data(1,20\%),frighten 8 data(9,6\%). And the most frequently strategies used by Eminem in his song is Use taboo words 56 data $(67,46 \%)$.
\end{abstract}

\footnotetext{
Nama $\quad$ : Lilik Suryani ${ }^{1}$, Rajid Khurniawan ${ }^{2}$

Instansi : Prodi Pendidikan Bahasa Inggris FKIP Universitas Billfath

Alamat instansi : Komplek PP. Al Fattah Siman Sekaran Lamongan Jawa Timur

Surel : suryanililik2525@gmail.com ${ }^{1}$, rajidkhurniawan@gmail.com ${ }^{2}$
}

Different countries have different culture. The origin of latin word culture means to tend, to cultivate and to till among others things (Tucker,1931). Impoliteness is understood differently by every people. Kluckhohn( 1951:154) stated culture consists in patterned ways of thinking, feeling and reacting, acquired and transmitted mainly by symbols of human groups, including their the the search 
for whatever ecological, sociological and culture variables might link with established variations in human behavior. People from different countries have different definitions of impoliteness and they also have different standards of impoliteness. The Impoliteness understood in Indonesia will be different from impoliteness understood in America.The standard of impoliteness is influenced by culture. The culture where people of society live will create the standards of impoliteness. Let me give one sample, when a young man talking directly with an old man than he saw directly their eyes of the old man, this attitude is polite when this is applied in American Culture. In America when somebody talking to someone he should watch the face of somebody, which means he listens carefully, talking seriously, and pay attention to. That behavior shows respect to the listener and speaker. But it will be the opposite when that behavior is applied in Indonesia. In Indonesia when a young man speaks with an old,man then he saw directly the face or the eyes of the old man it can be defined as not polite behavior attitude. The most polite action in a particular culture can be the most impolite action in a different culture.

In this research, the researcher used Impoliteness strategies from Jonathan Culpeper. Professor Jonathan Culpeper is a Lecturer from the department of linguistics and English language from Lancaster University. Jonathan Culpeper is an expert on pragmatic. In this research, the researcher used impoliteness strategies to investigate Eminem's songs.Impoliteness is FTA or a facethreatening act. It means impoliteness is utterance which ignites conflict. According to Culpeper (2010)'Impoliteness is a negative attitude towards specific behaviors occurring in specific contexts. It is sustained by expectations, desire, and beliefs about social organization, including, in particular, how one person's or group's identities are mediated by others in interaction. Situated behaviors are viewed negatively when they conflict with how one expects them to be, what one wants them to be and how one thinks they ought to be. Such behaviors always have or are presumed to have emotional consequences for at least one participant that is the cause or are presumed to offend. Various factors can exacerbate how offensive an impolite behavior is taken to be, including for example whether one understands a behavior to be strongly intentional or not. Culpeper divided impoliteness strategies into some parts, here there are Bald on record impoliteness, Positive impoliteness, Negative impoliteness, Sarcasm or mock politeness, Withhold politeness. Based on impoliteness strategies from Culpeper (1996) the researcher analyzed song lyrics Eminem songs. Eminem is a great singer in the world. He is a very famous rapper-singer. Eminem songs are very famous. But Eminem songs are very controversial. Rap is one of the four elements of hip-hop culture. Rap is a vocal technique that speaks quickly, and the singer is called a rapper. A rapper is accompanied by a band or DJ Rap can also be traced back to its African roots, where centuries before Hip-in other words impoliteness is utterances which ignite conflict. Hop music existed. West Africa had provided rhythmic stories called griots, which are more than drums and sparse instrumentation. This connection has been recognized by today's artists.

Usually, rappers are like ordinary singers, namely singing solo. Examples are Nas, Jay $-\mathrm{Z}$ and Kanye West. Some rappers are members of the band, for example, Mike Shinoda of Link Park. Generally, rappers are black because many rappers come from the suburbs of the United States. Among the few rappers who are white are Eminem, Mackle more, and Pit bull. Rappers are often referred to as MC or Emcee ( Master of Ceremony ). In Jamaica, the term rapper can be called Dee Jay like Sean Paul.In Indonesia, rap music has developed and become one of the music genres that have received attention. Local musicians whose works of rap or hip-hop enlivened the Indonesian music scene include Iwa K, Soul ID, Saykoji, Fade to Black (Bondan Prakoso \& Fade 2 Black), Batik Tribe, 8 Ball. The newest type of music available is Trip Hop, which is a combination of jazz and Hip - hop, one of the Indonesian Trip Hop musicians who have a strong rap element is Aji Kikuta. Marshall Bruce Mathers III (born October 17, 1972), known professionally as Eminem (often stylized as EMINEM), is a rapper, songwriter, record producer, record executive.

Eminem is the best-selling artist of the 2000s in America. Throughout his career, he has had a number one album on the Billboard 200 and five number-one singles on the Billboard Hot 100.With more than 47.4 million albums and 107.5 million singles sold in the US and 220 million records globally, he is one of the top-selling artists. best-selling worldwide and declared as one of the best and most influential artists in music history. He is the only one to have eight consecutive albums debut at number one on the Billboard 200. [1] Rolling Stone ranked him 12th on their list of 100 Best Artists of All Time, calling him the "King of Hip Hop".Following his debut album Infinite (1996) and later 
Slim Shady EP (1997), Eminem was signed to Dr. Dre's Aftermath Entertainment and quickly gained popularity in 1999 with The Slim Shady LP, which earned him his first Grammy Award for Best Rap Album. His next two albums, in 2000 entitled The Marshall Mathers LP and in 2002 entitled The Eminem Show, were a worldwide success, with diamonds certified for U.S. sale. and both albums won the Best Rap Album Grammy Awards - making Eminem the first artist to win this award for his three consecutive albums. His album was followed by Encore in 2004, again receiving critical and commercial success. Eminem took time off after touring in 2005, releasing Relapse in 2009 and Recovery in 2010. Both albums won Grammy Awards and Recovery was the best-selling album of 2010 worldwide, the second time he had the best-selling album worldwide (after The Eminem Show).

Eminem's eighth album, in 2013 The Marshall Mathers LP 2, won two Grammy Awards, including Best Rap Album; this earned him the record for most wins in that category and his Grammy total of 15. [2] In 2017, he released his ninth studio album, Revival. On August 31, 2018, Eminem released his tenth studio album, Kamikaze, [3] on the online listening services Apple Music, Spotify, and Amazon Music.Aside from his solo career, Eminem was an original member of the Midwest hip hop group Soul Stone and D12. He is also known for his collaborations with fellow Detroit rapper Royce da 5'9 "; they are both known as Nice Meets Evil. Eminem has several other ventures, including Cilok Restaurant, with manager Paul Rosenberg, which helps the careers of artists such as \$ 50. Eminem also created his channel, Shade 45, on Sirius XM Radio. In November 2002, he was cast in the hip hop film 8 Mile, which won the Academy Award for Best Original Song for the song "Lose Yourself", making him the first rap artist to ever win. [4] Eminem has made several supporting appearances in films such as Wash (2001), Funny People (2009), and The Interview (2014), and the television series Entourage (2010).

This research investigated Eminem songs title kill you,Kim, and Marshal Mathers. The researcher investigated three songs of Eminem and the researcher used Impoliteness strategies from Jonathan Culpeper.The previews research done by others researchers to take the research position. Here they are, Ratnawati (2014) investigated impoliteness in Indonesian EFL Students, particularly the perception of impoliteness used in the complaint by Indonesian EFL Students. Sifianou (2013) investigated impoliteness in globalization affects the expression of politeness and impoliteness in the present-day socio-cultural reality of major economic, political, social, and culture change. Vogel (2014) investigated Puzzles of impoliteness and politeness within a Formal Semantics of Offensive Language. Triyaningsih (2015) investigated impoliteness in Ron Clark Story Movie. Hartono (2014) investigated impoliteness used in command by characters in One Piece Comic Scrip. Shofyan (2015) investigated impoliteness in Easy A Movie. Latinen (2011) investigated impoliteness in verbal and non-verbal impoliteness in The American Hospital Drama House M,D. Khosravi (2015) investigated impoliteness in the realization of impoliteness in reply articles published in academic journals in the field of applied linguistics as an instance of academic conflict. Karina and Putri (2013) investigated impoliteness in Simon Cowell's utterance in The X-Factor USA Reality Show. Wibowo and Kuntjara (2012) investigated impoliteness strategies are used on online comments on an Indonesian football website. And what makes this research different from others is because this research investigated Eminem's songs title kill you, Kim and Marshal Maters used impoliteness strategies from Jonathan Culpeper. According to the researcher, this will be interesting to investigate Eminem's controversial songs with impoliteness strategies from Culpeper.

\section{REVIEW RELATED LITERATURE}

Impoliteness strategies are part of pragmatic, this is important to know the relationship between pragmatic and impoliteness strategies. Many experts define the term pragmatic. Brown and Levinson (1983:9) defined pragmatics as a study of those relations between language and context that are grammaticalized encode in the structure of language. It means to find the meaning according to pragmatic we have to identify text and context. Text and context create the true meaning. If we separated text and contact this will be very dangerous. The reason is that when we separated the text and context people will have a misunderstanding about the true meaning of the sentences. Crystal (1997: 301) defined pragmatic as the study of language at the point of that view of its user, especially of the choices they make, the constraints they encounter in using language in social interactions, and the effect their use of language has on another participant in the act of communication. According to 
KARANGAN: Jurnal Kependidikan, Pembelajaran, dan Pengembangan, Vol 3, No 2, Bulan September, Tahun 2021, Hal 116-121

Crystal, pragmatic is the study of language where people will have a different view of the interpretation of sentences. For example when a speaker speech in front of the public than there many audiences listened to the speaker's speech. The audients who listen to the same speech from the speaker will have different interpretations about what the speaker means in his speech. The audiences have different intelligence and different experience,this interprets the audience as becoming different. For more simple a teacher who teaches in a class in front of 40 students. The 40 students will have different views about a topic explained by the teacher. although the teacher teaches the same topic the understanding of 40 students about the topic will be different.

According to Culpeper(2005) in Bousfield(2007), the five-point model identifies some separate ways (super strategies) in which impoliteness can be generated and conveyed. Culpeper (2005) divided impoliteness strategies into some parts, here there are :

1. Bald on record impoliteness

According to the developments of the model (Culpeper 1996,2005), bald on record impoliteness is seen as typically being deployed where there is much face at stake, where there is an intention on the part of the speaker to attack the face of the hearer and or where the speaker does not have the power to (safely) utter an impolite utterance. That is, the utterance is deployed in a direct, unambiguous manner (fully following Grice's $(\{1975\}, 1989)$ maxims).. wherethe face is not irrelevant or minimized (Culpeper 2005:41).

2. Positive impoliteness

Attacking your want to be approved of, which Culpeper (2005:41)explicitly links with Spencer-Oatey's (2002) quality face and elements of sociality face). Positive impoliteness, according to the latest instantiation of the moel (Culpeper 2005:41) involves"the use of strategies deployed to damage the recipient's positive face wants". Examples of such strategies from Culpeper (1996) include:

- Ignore, snub the other

- Exclude the other from an activity.

- Disassociate from the other

- Be disinterested, unconcerned, unsympathetic

- Use inappropriate identity markers

- Use obscure or secretive language

- Seek disagreement

- Make the other feel uncomfortable

- Use taboo words

- Call the other name

3. Negative impoliteness

Attacking your freedom of action, which Culpeper (2005:41) explicitly links with SpencerOatey's (2002) equity right. Further, he (2005) suggests that this negative face also overlaps with association rights, to some extent). Negative Impoliteness, according to the latest instantiation of the model (Culpeper 2005:41) involves "the use of strategies deployed to damage the recipient's negative face wants". Examples of such strategies from Culpeper (1996) include:

- Frighten

- Condescend, scorn or ridicule

- Invade the other's space

- Explicitly associate the other with a negative aspect

- Put the other's indebtedness on record.

4. Sarcasm or mock politeness

This super strategy was introduced by Culpeper (2005: 43-44) as a replacement to the metastrategic nature of sarcasm (which hadpreviously been considered on the same level as the other super strategies; Culpeper 1996). Off-record impoliteness is one where the offense is conveyed indirectly by way of an implicature and could be can be celled (denied, or an account, postmodification or another type of elaboration offered, etc) but where according to Culpeper (2005:44) one attributable intention outweighs any others.

5. Withhold politeness

Keep silent or fail to act where politeness work is expected. Culpeper (1996:357) notes that impoliteness may be realized through,(...) the absence of politeness work where it would be expected. 
KARANGAN: Jurnal Kependidikan, Pembelajaran, dan Pengembangan, Vol 3, No 2, Bulan September, Tahun 2021, Hal 116-121

Culpeper (2005) gives the example that "failing to thank someone for a present may be taken as deliberate impoliteness."Culpeper further notes that Brown and Levinson (1987) would appear to agree with the face-threatening aspects and implications surrounding the withholding of politeness when they claim : (...) politeness has to be communicated, and the absence of communicated politeness may, ceteris paribus, be taken as the absence of a polite attitude. (Brown and Levinson 1987:5, as cited in Culpeper 1996:357).

\section{RESEARCH METHOD}

The researcher used descriptive qualitative .The researcher used impoliteness strategies from Jonathan Culpeper to analyze the data.The researcher took three song of Eminem title Kill You, Marshall Maters and Kim.The scope of this research is the utterance of Eminem in his songs above which contain impoliteness. The researcher investigated what kinds of impoliteness strategies used by Eminem in his song title Kil You, Marshal Mathers and Kim. And what is the most frequently impoliteness strategies used by Eminem in his songs.

\section{FINDING}

Based on the analysis, the researcher found impoliteness strategies used in the lyrics song of Eminem include bald on record, positive impoliteness, negative impoliteness, and sarcasm. This study did not find withhold politeness in the lyrics song of Eminem. The total impoliteness used by Eminem in his songs is 83 data. The total data of impoliteness are bald on record 11 data(13,25\%),ridicule(negative impoliteness) 6 data $(9,63 \%)$, use taboo words 56 data $(67,46 \%)$,Sarcasm 1 data(1,20\%), call the other names 1 data(1,20\%),use inappropriate identity markers 1 data(1,20\%),exclude the other from an activity 1 data(1,20\%),frighten 8 data(9,6\%). And the most frequently strategies used by Eminem in his song is Use taboo words 56 data $(67,46 \%)$.

\section{CONCLUSION}

Base on the analysis the researcher concluded that Eminem used Bald on Record, Negative Impoliteness and Sarcasm in his songs title Kill You, Marshall Mathers and Kim. The most frequently impoliteness strategies used by Eminem is sarcasm. In his songs the researcher did not find Positive impoliteness and Withhold politeness. Base on this research the researcher concluded that impoliteness can be used as part of entertainment. Eminem proved that he has totally successful used impoliteness to hypnosis his music listener. Eminem is a Genius musician who is able to used impoliteness in his song and million people in the world totally enjoy his songs. Although Eminem songs are controversial and full of dirty lyric but people in the world enjoy his song. This proved that he is a genius. Eminem is perhaps the only one in the world who is able to use impoliteness to entertain people in his songs. And he proved that he got massive successful with his controversial songs. Other people cannot do or cannot imitate what Eminem did. The researcher want to say that do not do what Eminem did in his song because the only one in this world who is allowed to used impoliteness in song is only Eminem.

\section{REFERENCES}

Ahmadi, Alireza and S. Heydari, Kamal.2011. Should we teach the impoliteness language? A study of Iranian EFL learners, teachers, experts and non Iranianexperts'attitudes.Finland : Academy Publisher.

Ardinoglu, Nazife.2013. Politeness and Impoliteness Strategies : an analysis of gender differences in Geralyn. Horton's plays. Turkey. Elseiver Ltd.

Bousfield, Derek and A. Locher, Mirriam (ed).2008. Impoliteness in Language: Studies on its Interplay with Power in Theory and Practice. Berlin: Walter de Gruyter GmbH \& Co.

Bousfield, Derek. 2007. Impoliteness, preference organization and conductivity. Walter de Gruyer,pp.1-33.

Bousfield, Derek.2008. Impoliteness in Interaction.Amsterdam and Philadelphia : John Benjamins Publishing Co. 
KARANGAN: Jurnal Kependidikan, Pembelajaran, dan Pengembangan, Vol 3, No 2, Bulan September, Tahun 2021, Hal 116-121

Chang, Wei-Lin.2008. Australian and Chinese perceptions of (im)politeness in an intercultural apology. Griffth University.

Culpeper, Jonathan.2005. Impoliteness and entertaintment in the television quiz show : The Weakest Link. Walter de Gruyter, pp.35-72.

Culpeper, Jonathan and Leyla, Marti. Cross-cultural variation in the perception of impoliteness: A study of impolitenessevents reported by students in England, China, Finland, Germany and Turkey. Journal Intercultural Pragmatics,pp.1-20.

Culpeper, Jonathan. 2011. Impoliteness : Using language to cause offence. The University of Texas at Arlington.

Culpeper, Jonathan.2009.Using language to cause offence: ESRCEndof Award Report.

F, Jumani, Wan, Ibrahim Noraini and Maros, Marlyna. 2014. Perception of Impoliteness in counter service discourse. Malysia :Elsiver Ltd, pp.118-125.

Fauziati, Endang. 2011. Psycho Linguistics : an Introduction. Surakarta : PT. Era PustakaUtama.

Fauziyati, Endang.2015. Teaching English as a Foreign Language : Principle and Practice : PT. Era PustakaUtama.

Fauziyati, Endang. Linguistic Impoliteness: A Brief Literature Review. University Muhammadiyah of Surakarta.

G, Fernandez, Francisco.2014. Impoliteness, Psuedo-Politeness, Strategies Politeness?On The Nature of Communicative Behavior In Electoral Debates. Universidad Complutnese de Madrid, pp.1576-4237.

G.P, Wibowo and K. Kuntjara. Impoliteness strategies used on online comments in an Indonesian foot ball website. Petra CristianUniversity, Surabaya , Indonesia.

Haugh, Michael.2004. Humour, face and impoliteness in getting acquainted. Journal of Pragmatics,pp.1-19.

Haugh, Michael.2013. Disentangling face, face work and impoliteness.Soprag, pp.46-73.

Jamet Deais and Jobert Manuel.2013. Aspects og Linguistic Impoliteness . London: Cambrige Scholars Publishing.

K. Karina, Lindy and P. Ika, Noerhayati.2013. Impoliteness in Simon Cowell's utterances in The X Factor USA Reality Show.English Departement, Airlangga University.

Kecskes, Istuan.2015. Introcultural impoliteness. Elsiver,pp.43-47.

Khosravi, Mohadese.2015. A Pragmatic Analysis of Impoliteness in Reply Articles as an Instance of Academic Conflict.Iran: Journal of Applied Linguistics and Language Research,pp.223-231.

Methias.W, Norice.2011. Impoliteness or underpoliteness: An analysis of a christmas dinner scene from Dickens's Great Expectations. Journal of King Saud University,pp.11-18.

Mohammad, Mohammadi and H. Seyyed, TamimiSa'd.2014. Native Speaker's assessment of (im)politeness of non-native speakers'requests.Iran: Urmia University.

Park, Anna, L. William and Robinson, Rebecca.2014. More rudeness: reliable personality predictors of verbal rudeness and other ugly confrontational behaviors. Emerald Group.pp,26-47.

Perelmutter, Renee.2010. Impoliteness recycled: Subject ellipsis in modern Russian Complaint discourse : Elsevier, pp.3214-3231.

Ratnawinata, Eni. A Cross Sectional Study on The Perception of (im)politeness used in complaint by Indonesian EFL Students. Surakarta: University Muhammadiyah of Surakarta.

Saidi, Mauvadat and Khosravi, Mohadese.2015. EFL Learners' Perceptions of Impoliteness: The Posible Gender Differences: KhateSefid Press.

Sifianou, Maria.2013. The impact of globalisation on politeness and impoliteness. Greece. Elseiver, pp.86-102.

Stockdale, Laura, T. Sarah and Coyne, M.2013.Sex differences in verbal aggression used in romantic relationships: a meta-analytic study and review. USA: Emerald Group.

Vilkki, Liisa. Politeness, face and face work: current issues. Fred karlsson,pp.322- 332.

Vogel, Carl. Some Puzzles of Politeness and Impoliteness within a Formal Semantics of Offensive Language. Ireland: Trinity College Dunblin.

Tutas, Nazan and A. Demirkol, Nihal.2014. Direct-Indirect Impoliteness and Power Struggles in Harold Pinter's plays. Elseiver,pp.370-376. 